\title{
PERAN STRATEGIS BADAN PENYELESAIAN SENGKETA KONSUMEN (BPSK) MENURUT UNDANG-UNDANG NOMOR 8 TAHUN 1999 TENTANG PERLINDUNGAN KONSUMEN
}

\author{
IRFANSYAH \\ Fakultas Hukum Universitas Lancang Kuning \\ irfansyah@unilak.ac.id
}

\begin{abstract}
Consumer protection is any effort that ensures legal certainty to protect consumers. The legal basis that regulates consumer protection in Indonesia is Law Number 8 of 1999 concerning Consumer Protection. The method used in this research is normative legal research, using a statutory approach. According to Article 45 Paragraph (1) of Law Number 8 of 1999 concerning Consumer Protection, it is emphasized that every consumer who is injured can sue business actors through an institution that is tasked with resolving disputes between consumers and business actors or through courts within the general court. In order to resolve consumer disputes outside the court, the government is mandated to establish a Consumer Dispute Resolution Agency. In handling and resolving consumer disputes, the Consumer Dispute Resolution Agency forms an assembly consisting of at least 3 (three) members representing elements of government, elements of consumers, and elements of business actors. According to Article 54 Paragraph (3) of Law Number 8 of 1999 concerning Consumer Protection, it is confirmed that the decision of the assembly formed by the Consumer Dispute Resolution Agency is final and binding. Settlement of disputes through the Consumer Dispute Resolution Agency doesn't eliminate criminal responsibility so that the decision of the assembly formed by the Consumer Dispute Resolution Agency is sufficient initial evidence for investigators to carry out investigations.
\end{abstract}

Keywords: Consumer Protection; BPSK; Strategic Role

Abstrak: Perlindungan konsumen adalah segala upaya yang menjamin adanya kepastian hukum untuk memberi perlindungan kepada konsumen. Dasar hukum yang mengatur mengenai perlindungan konsumen di Indonesia adalah Undang-Undang Nomor 8 Tahun 1999 tentang Perlindungan Konsumen. Metode yang digunakan dalam penelitian ini adalah penelitian hukum normatif, dengan menggunakan pendekatan peraturan perundang-undangan. Menurut Pasal 45 Ayat (1) Undang-Undang Nomor 8 Tahun 1999 tentang Perlindungan Konsumen ditegaskan bahwa setiap konsumen yang dirugikan dapat menggugat pelaku usaha melalui lembaga yang bertugas menyelesaikan sengketa antara konsumen dan pelaku usaha atau melalui peradilan yang berada di lingkungan peradilan umum. Dalam rangka penyelesaian sengketa konsumen di luar pengadilan, pemerintah diamanatkan untuk membentuk Badan Penyelesaian Sengketa Konsumen (BPSK). Dalam menangani dan menyelesaikan sengketa konsumen, Badan Penyelesaian Sengketa Konsumen (BPSK) membentuk majelis yang beranggotakan minimal 3 (tiga) orang yang mewakili unsur pemerintah, unsur konsumen, dan unsur pelaku usaha. Menurut Pasal 54 Ayat (3) Undang-Undang Nomor 8 Tahun 1999 tentang Perlindungan Konsumen ditegaskan bahwa putusan majelis yang dibentuk oleh Badan Penyelesaian Sengketa Konsumen (BPSK) bersifat final dan mengikat. Penyelesaian sengketa melalui Badan Penyelesaian Sengketa 
Konsumen (BPSK) tidak menghilangkan tanggung jawab pidana sehingga putusan majelis yang dibentuk oleh Badan Penyelesaian Sengketa Konsumen (BPSK) merupakan bukti permulaan yang cukup bagi penyidik untuk melakukan penyidikan.

Kata Kunci: Perlindungan Konsumen; BPSK; Peran Strategis

\section{A. Pendahuluan}

Konsumen adalah setiap orang pemakai barang dan/atau jasa yang tersedia dalam masyarakat, baik bagi kepentingan diri sendiri, keluarga, orang lain, maupun makhluk hidup lain dan barang dan/atau jasa tersebut tidak untuk diperdagangkan (Eli Wuria Dewi, 2015). Pada dasarnya, prinsip ekonomi pelaku usaha adalah mencari keuntungan yang sebesar-besarnya dengan modal yang sekecil-kecilnya. Prinsip ini berpotensi merugikan kepentingan konsumen, baik secara langsung maupun tidak langsung. Oleh karena itu, negara mempunyai peran yang penting untuk melindungi konsumen sebagai objek bisnis dari para pelaku usaha.

Perlindungan konsumen adalah segala upaya yang menjamin adanya kepastian hukum untuk memberi perlindungan kepada konsumen (Janus Sidabalok, 2010). Dasar hukum yang mengatur mengenai perlindungan konsumen di Indonesia adalah UndangUndang Nomor 8 Tahun 1999 tentang Perlindungan Konsumen. Dalam rangka melindungi hak-hak konsumen, Undang-Undang Nomor 8 Tahun 1999 tentang Perlindungan Konsumen mengatur bahwa setiap konsumen yang dirugikan dapat menggugat pelaku usaha melalui peradilan yang berada di lingkungan peradilan umum. Akan tetapi, semakin menurunnya kepercayaan masyarakat terhadap lembaga peradilan akibat kasus-kasus korupsi yang melibatkan hakim membuat konsumen berada pada posisi yang lemah (Andrew Shandy Utama, 2019). Apalagi jika melawan pelaku usaha seperti perusahaan besar yang memiliki kekuatan secara finansial.

Menyikapi fenomena tersebut, Undang-Undang Nomor 8 Tahun 1999 tentang Perlindungan Konsumen memberikan alternatif pilihan bagi konsumen dalam menyelesaikan sengketa, yaitu penyelesaian sengketa di luar pengadilan melalui Badan Penyelesaian Sengketa Konsumen (BPSK). Dari latar belakang masalah yang telah diuraikan di atas, maka permasalahan yang dibahas dalam penelitian ini adalah bagaimanakah peran strategis Badan Penyelesaian Sengketa Konsumen (BPSK) menurut Undang-Undang Nomor 8 Tahun 1999 tentang Perlindungan Konsumen?

\section{B. Metodologi Penelitian}

Penelitian hukum adalah suatu kegiatan ilmiah yang didasarkan pada metode, sistematika, dan pemikiran tertentu yang bertujuan untuk mempelajari satu atau beberapa gejala hukum tertentu dengan jalan menganalisanya (Soerjono Soekanto, 2007). Metode yang digunakan dalam penelitian ini adalah penelitian hukum normatif, dengan menggunakan pendekatan peraturan perundang-undangan. Penelitian hukum normatif adalah suatu proses untuk menemukan aturan hukum, prinsip-prinsip hukum, maupun doktrin-doktrin hukum guna menjawab isu-isu hukum yang dihadapi (Peter Mahmud Marzuki, 2011). Sumber data yang digunakan dalam penelitian ini adalah data sekunder, yaitu data yang diperoleh dari peraturan perundang-undangan, jurnaljurnal ilmiah, dan literatur hukum. Teknik pengumpulan data yang digunakan dalam penelitian ini adalah studi kepustakaan. Teknik analisis data yang digunakan dalam penelitian ini adalah analisis kualitatif. 


\section{Hasil dan Pembahasan}

Hubungan yang tercipta antara pelaku usaha dan konsumen merupakan hubungan hukum yang dilandasi oleh kepercayaan terhadap barang dan/atau jasa yang diperdagangkan. Hubungan yang baik antara pelaku usaha dan konsumen dapat memberikan dampak yang positif bagi roda perkonomian nasional. Sebaliknya, hubungan yang buruk antara pelaku usaha dan konsumen berdampak negatif terhadap roda perekonomian nasional. Melindungi hak-hak konsumen merupakan tanggung jawab pemerintah sebagai penyelenggara negara karena pada dasarnya semua masyarakat adalah konsumen (Yusuf Shofie, 2008).

Dasar hukum yang mengatur mengenai perlindungan konsumen di Indonesia adalah Undang-Undang Nomor 8 Tahun 1999 tentang Perlindungan Konsumen. Menurut Pasal 45 Ayat (1) Undang-Undang Nomor 8 Tahun 1999 tentang Perlindungan Konsumen ditegaskan bahwa setiap konsumen yang dirugikan dapat menggugat pelaku usaha melalui lembaga yang bertugas menyelesaikan sengketa antara konsumen dan pelaku usaha atau melalui peradilan yang berada di lingkungan peradilan umum.

Sejalan dengan itu, menurut Pasal 45 Ayat (2) Undang-Undang Nomor 8 Tahun 1999 tentang Perlindungan Konsumen ditegaskan bahwa penyelesaian sengketa konsumen dapat ditempuh melalui pengadilan atau di luar pengadilan berdasarkan pilihan sukarela para pihak yang bersengketa. Dalam rangka penyelesaian sengketa konsumen di luar pengadilan, Undang-Undang Nomor 8 Tahun 1999 tentang Perlindungan Konsumen mengamanatkan kepada pemerintah untuk membentuk Badan Penyelesaian Sengketa Konsumen (BPSK) di kabupaten/kota.

Menurut Pasal 52 Undang-Undang Nomor 8 Tahun 1999 tentang Perlindungan Konsumen disebutkan bahwa tugas dan wewenang Badan Penyelesaian Sengketa Konsumen (BPSK) meliputi:

1. Melaksanakan penanganan dan penyelesaian sengketa konsumen dengan cara melalui mediasi atau arbitrase atau konsiliasi.

2. Memberikan konsultasi perlindungan konsumen.

3. Melakukan pengawasan terhadap pencantuman klausula baku.

4. Melaporkan kepada penyidik umum apabila terjadi pelanggaran ketentuan dalam Undang-Undang Nomor 8 Tahun 1999 tentang Perlindungan Konsumen.

5. Menerima pengaduan, baik tertulis maupun tidak tertulis, dari konsumen tentang terjadinya pelanggaran terhadap perlindungan konsumen.

6. Melakukan penelitian dan pemeriksaan sengketa perlindungan konsumen.

7. Memanggil pelaku usaha yang diduga telah melakukan pelanggaran terhadap perlindungan konsumen.

8. Memanggil dan menghadirkan saksi, saksi ahli, dan/atau setiap orang yang dianggap mengetahui pelanggaran terhadap Undang-Undang Nomor 8 Tahun 1999 tentang Perlindungan Konsumen.

9. Meminta bantuan penyidik untuk menghadirkan pelaku usaha, saksi, saksi ahli, atau pelaku usaha yang diduga telah melakukan pelanggaran terhadap perlindungan konsumen dan setiap orang yang dianggap mengetahui pelanggaran terhadap Undang-Undang Nomor 8 Tahun 1999 tentang Perlindungan Konsumen yang yang tidak bersedia memenuhi panggilan Badan Penyelesaian Sengketa Konsumen (BPSK). 
10. Mendapatkan, meneliti, dan/atau menilai surat, dokumen, atau alat bukti lain guna penyelidikan dan/atau pemeriksaan.

11. Memutuskan dan menetapkan ada atau tidak adanya kerugian di pihak konsumen.

12. Memberitahukan putusan kepada pelaku usaha yang melakukan pelanggaran terhadap perlindungan konsumen

13. Menjatuhkan sanksi administratif kepada pelaku usaha yang melanggar ketentuan Undang-Undang Nomor 8 Tahun 1999 tentang Perlindungan Konsumen.

Dalam menangani dan menyelesaikan sengketa konsumen, Badan Penyelesaian Sengketa Konsumen (BPSK) membentuk majelis yang beranggotakan minimal 3 (tiga) orang yang mewakili unsur pemerintah, unsur konsumen, dan unsur pelaku usaha. Menurut Pasal 54 Ayat (3) Undang-Undang Nomor 8 Tahun 1999 tentang Perlindungan Konsumen ditegaskan bahwa putusan majelis yang dibentuk oleh Badan Penyelesaian Sengketa Konsumen (BPSK) bersifat final dan mengikat. Eksekusi terhadap putusan majelis tersebut dapat dimintakan penetapan eksekusinya kepada pengadilan negeri di tempat konsumen yang dirugikan.

Apabila telah dipilih upaya penyelesaian sengketa konsumen di luar pengadilan melalui Badan Penyelesaian Sengketa Konsumen (BPSK), maka gugatan melalui pengadilan hanya dapat ditempuh apabila upaya tersebut dinyatakan tidak berhasil oleh salah satu pihak atau para pihak yang bersengketa (Ahmadi Miru dan Sutarman Yodo, 2004).

Menurut Pasal 45 Ayat (3) Undang-Undang Nomor 8 Tahun 1999 tentang Perlindungan Konsumen diatur bahwa penyelesaian sengketa melalui Badan Penyelesaian Sengketa Konsumen (BPSK) tidak menghilangkan tanggung jawab pidana yang diatur dalam Undang-Undang Nomor 8 Tahun 1999 tentang Perlindungan Konsumen. Oleh karena itu, menurut Pasal 56 Ayat (5) Undang-Undang Nomor 8 Tahun 1999 tentang Perlindungan Konsumen ditegaskan bahwa putusan majelis yang dibentuk oleh Badan Penyelesaian Sengketa Konsumen (BPSK) merupakan bukti permulaan yang cukup bagi penyidik untuk melakukan penyidikan.

\section{Penutup}

Perlindungan konsumen adalah segala upaya yang menjamin adanya kepastian hukum untuk memberi perlindungan kepada konsumen. Dasar hukum yang mengatur mengenai perlindungan konsumen di Indonesia adalah Undang-Undang Nomor 8 Tahun 1999 tentang Perlindungan Konsumen. Menurut Pasal 45 Ayat (1) UndangUndang Nomor 8 Tahun 1999 tentang Perlindungan Konsumen ditegaskan bahwa setiap konsumen yang dirugikan dapat menggugat pelaku usaha melalui lembaga yang bertugas menyelesaikan sengketa antara konsumen dan pelaku usaha atau melalui peradilan yang berada di lingkungan peradilan umum. Dalam rangka penyelesaian sengketa konsumen di luar pengadilan, pemerintah diamanatkan untuk membentuk Badan Penyelesaian Sengketa Konsumen (BPSK). Dalam menangani dan menyelesaikan sengketa konsumen, Badan Penyelesaian Sengketa Konsumen (BPSK) membentuk majelis yang beranggotakan minimal 3 (tiga) orang yang mewakili unsur pemerintah, unsur konsumen, dan unsur pelaku usaha. Menurut Pasal 54 Ayat (3) Undang-Undang Nomor 8 Tahun 1999 tentang Perlindungan Konsumen ditegaskan bahwa putusan majelis yang dibentuk oleh Badan Penyelesaian Sengketa Konsumen (BPSK) bersifat final dan mengikat. Penyelesaian sengketa melalui Badan Penyelesaian Sengketa Konsumen (BPSK) tidak menghilangkan tanggung jawab 
pidana sehingga putusan majelis yang dibentuk oleh Badan Penyelesaian Sengketa Konsumen (BPSK) merupakan bukti permulaan yang cukup bagi penyidik untuk melakukan penyidikan.

\section{Daftar Pustaka}

Ahmadi Miru dan Sutarman Yodo. 2004. Hukum Perlindungan Konsumen. Jakarta: Rajawali Pers.

Andrew Shandy Utama. 2019. Kepercayaan Masyarakat terhadap Penegakan Hukum di Indonesia. Ensiklopedia Social Review, Vol. 1, No. 3, Hal. 306-313.

Bambang Waluyo. 2016. Penegakan Hukum di Indonesia. Jakarta: Sinar Grafika.

Eli Wuria Dewi. 2015. Hukum Perlindungan Konsumen. Yogyakarta: Graha Ilmu.

Janus Sidabalok. 2010. Hukum Perlindungan Konsumen di Indonesia. Bandung: Citra Aditya Bakti.

Munir Fuady. 2002. Pengantar Hukum Bisnis. Bandung: Citra Aditya Bakti.

Peter Mahmud Marzuki. 2011. Penelitian Hukum. Jakarta: Kencana.

Soerjono Seokanto. 2007. Pengantar Penelitian Hukum. Jakarta: UI Press.

Yusuf Shofie. 2008. Hukum Perlindungan Konsumen di Indonesia. Bandung: Citra Aditya Bakti.

Zainal Asikin. 2016. Hukum Dagang. Jakarta: Rajawali Pers. 